\title{
Zarys dziejów parafii we Florynce (do 1951 roku)
}

\begin{abstract}
Резуме
Нарыс діів парохіi во Фльоринці

Допис є ескізом о істориі грекокатолицкой парохіі во Фльоринці. Коротко представлено в ним історию місцевости, описано маєток паpoxii та найважнійшы подіi з жытя Фльоринчан. Особливу увагу посвячено священникам парохіi (од XVIII ст.), для котрых опрацувано короткы біограмы. Накрыслено тіж історию монастыря о. Студитів.
\end{abstract}

Ключовы слова: Фльоринка, Вафка, Лемковина, грекокатолицка парохія, церков, Студиты

\begin{abstract}
Florynka Parish. Outline of History

The article is a brief outline of the history of the Greek Catholic parish in Florynka. It contains a short history of the village, a description of the parish property and the most important events in the life of the community. It also includes the biographical notes of following priests working in this parish (from the eighteenth century) as well as the Studite monastery.
\end{abstract}

Keywords: Florynka, Wawrzka, Lemkoland, Greek Catholic parish, church, Studite Monks 
Florynka powstała prawdopodobnie w drugiej połowie XIV w., jednak nieznane są żadne źródła historyczne wskazujące precyzyjnie datę jej lokacji. Do 1391 r. stanowiła własność królewską i wchodziła w skład latyfundium muszyńskiego. W tym samym roku dobra królewskie zostały przekazane biskupowi krakowskiemu Janowi Radlicowi przez Władysława Jagiełłę (Leszczyńska-Skrętowa, Sikora 1980, 683). Akt ten stanowić miał zwrot dawnej własności kościelnej, do której należała Muszyna wraz z przyległościami, zajętej na początku XIV w. przez Władysława Łokietka i włączonej później do królewszczyzn. Wśród istniejących miejscowości przekazanych przez Jagiełłę widnieje Flornicowa, która interpretowana jest właśnie jako Florynka (Leszczyńska-Skrętowa, Sikora 1980, 683). W 1474 r. Florynka spalona została podczas najazdu wojsk węgierskich Macieja Korwina Hunyadego (Przyboś 2007, 33).

Kolejna wzmianka o Florynce pochodzi dopiero z 1529 r., kiedy wymieniana jest jako płatnik czynszu (45 gr) i obiednego - opłacanego 2 razy do roku czynszu mającego na celu utrzymanie właściciela klucza, który zjeżdżał do danej miejscowości na roki sądowe (Leszczyńska-Skrętowa 1968, 46). W 1574 r. Florynka została przeniesiona najpewniej z prawa niemieckiego na prawo wołoskie. Pierwotny dokument lokacyjny wsi miał ulec spaleniu, dlatego też relokacji dokonać miano „za pogorzałym prawem”. Sygnatariuszem nowego przywileju dla Florynki był biskup krakowski Franciszek Krasiński, a jej relokacja związana była z intensyfikacją akcji osadniczej na obszarze biskupiego klucza muszyńskiego - w tym samym roku wydano dokumenty lokacyjne dla nowopowstałych wsi: Banicy, Czyrnej, Polan, Berestu, Stawiszy i Wawrzki (Przyboś 2007, 33). Przywilej otrzymał sołtys Florynki, Klemens Worchacz, któremu nadano 2 łany, łąki, młyn, piłę tracką i po 2 dni pańszczyzny od kmieci (Czajkowski 1999, 81). W 1590 r. Hieronim Miedonowicz z Florynki otrzymał przywilej na lokację Piorunki (Czajkowski 1999, 82).

Po zakończeniu akcji osadniczej na początku XVII w. klucz muszyński, w skład którego wchodziły 2 miasta i 47 wsi, podzielony został na dwie grupy - wsi „popradnich” położonych wzdłuż Popradu i „zaleśnych”, które skupiały 18 wsi leżących w dorzeczu Białej. Do tej drugiej grupy należała Florynka i Wawrzka (Czajkowski 1999, 82). Ich mieszkańcy zobowiązani byli powinnościami biskupimi (na rzecz stołu biskupiego), cerkiewnymi (na rzecz plebana/ parocha), dworskimi (na rzecz dworu muszyńskiego i folwarków) oraz sołtysimi. Florynka pozostawała w dobrach biskupów krakowskich do czasów zajęcia państwa muszyńskiego w 1770 r. przez Austrię i taki stan własnościowy utrzymał się przez kolejnych 12 lat. W 1781 r. rząd austriacki przejął kontrolę nad 
całością dobór wchodzących w skład państwa muszyńskiego i przekazał je pod jurysdykcję skarbu państwa - Kamery. Na bazie dawnego klucza utworzone zostało dominium Muszyna - podstawowa jednostka administracyjna i sądownicza Galicji, która w niezmiennym kształcie funkcjonowała do połowy XIX w. Podobnie jak inne dawne dobra kościelne, dominium przeszło pod zarząd funduszu religijnego, który zasilały wpływy z dzierżawy pojedynczych wsi lub ich grup. Po uwłaszczeniu chłopów i likwidacji dominiów, Florynka i Wawrzka nadal pozostawały własnością c. k. Zarządu dóbr funduszowych w Muszynie, jednak jego stan posiadania na terenie wsi był już ograniczony do minimum należały do niego tylko karczma i zajazd we Florynce, prawo propinacji oraz grunta dominalne (Gazeta Lwowska 10.01.1873, 5). Pod koniec XVIII w. powierzchnia użytkowa Florynki wynosiła 2998 morgów i 1579 sążni kw., w tym gruntów dominalnych było 408 morgów i 122 sążni kw. Natomiast powierzchnia Wawrzki wynosiła 605 morgów i 152 skw., w tym grunta dominalne stanowiły 66 morgów i 1447 skw. (Falniowska-Gradowska 1982, 224-225).

W 1808 r. we Florynce znajdowały się 133 domostwa zamieszkiwane przez 187 rodzin. Liczba ludności wynosiła 835 osób, wśród których znajdowali się: 1 duchowny, 40 chłopów i 114 chałupników. W Wawrzce w tym czasie było 36 domów zamieszkiwanych przez 36 rodzin, przy ogólnej liczbie mieszkańców 229 - w tym 14 chłopów i 29 chałupników ${ }^{1}$. Niespełna wiek później Florynka liczyła 188 domów i 1107 mieszkańców, Wawrzka natomiast 55 domów i 317 mieszkańców. W 1931 r. ilość domów we Florynce nieznacznie spadła do 186, wzrosła natomiast liczba mieszkańców - do 1 124. W Wawrzce liczba domów nie uległa zmianie, wzrosła jednak liczba ludności - do 345 (Czajkowski 1999, 170).

Pod koniec XIX w. nastąpił rozwój wsi. W 1890 r. rozpoczęto budowę nowej szkoły (Czas 12.06.1890, 3), a po oddaniu budynku (istniejącego do lat 80. XX w.) szkołę przekształcono z filialnej na etatową (Czas 12.02.1892, 3). W 1891 r. wybudowano również nową szkołę filialną w Wawrzce (do tego czasu dzieci uczęszczały do szkoły we Florynce) (Szkolnictwo Ludowe 20.12.1981, 15). W lutym 1904 r. otworzono we Florynce urząd pocztowy, który funkcjonował we wsi do 20 października 1931 r., a po jego likwidacji Florynkę i Wawrzkę włączono do zamiejscowego okręgu doręczeń urzędu pocztowego w Grybowie (Kuryer Lwowski 12.02.1904, 5; Nowy Dziennik 4.11.1931, 9).

Jewuła Łukasz, Kargol Tomasz, Ślusarek Karol. Słownik miejscowości i elity miejskiej zachodniej Małopolski w latach 1772-1815. Dostęp: 25.11.2018. https://www.gospodarka-galicji.pl. Hasła: Florynka, Wawrzka. 
Na przełomie XIX i XX w. we wsi wybudowano duży tartak (w latach 30. działający pod nazwą Tartak Parowy „Florynka” Langsama i Janiczeka ${ }^{2}$ ), funkcjonował kamieniołom (należący do Pawła Musiała z Krakowa), z którego pozyskiwano materiał na blaty i schody (Tarnowianin. Kalendarz na rok 1895 1894), działał młyn wodny oraz duża karczma zajezdna, dzierżawiona przez Wojciecha Krzemińskiego (Kuryer Lwowski 23.08.1902, 4).

Przed I wojną światową planowano wybudować we Florynce kościół według projektu krakowskiego architekta Zdzisława Mączeńskiego ${ }^{3}$. Do koncepcji wrócono w pierwszej połowie lat 20., jednak ostatecznie wybór miejsca na budowę kościoła padł na sąsiednią Kąclową. Stało się to za sprawą testamentu legionisty Wojciecha Michałowskiego, który postanowił przekazać cały swój majątek parafii w Grybowie (na rzecz budowy kościoła w Kąclowej) (Laskowski 2017, 184).

W czasie I wojny światowej Florynka została zajęta przez wojska rosyjskie. Pamiątką po toczących się w okolicy walkach jest cmentarz wojenny, na którym spoczywa 87 żołnierzy armii austro-węgierskiej i 16 armii rosyjskiej (Broch, Hauptmann 1993, 144). Od grudnia 1918 r. do 1920 r. Florynka stała się nieformalną stolicą Ruskiej Republiki Ludowej - pierwszego łemkowskiego organizmu polityczno-administracyjnego ${ }^{4}$. W 1928 r. większość mieszkańców Florynki i Wawrzki przeszła na prawosławie i w tych miejscowościach wzniesiono nowe cerkwie prawosławne ${ }^{5}$.

W 1945 r. wyjechało z Florynki na Ukrainę ok. 60 rodzin. Pozostałą we Florynce ludność łemkowską wysiedlono 29 czerwca 1947 r. w ramach akcji „Wisła” na tzw. Ziemie Odzyskane.

Nieznany jest akt erekcyjny cerkwi we Florynce, więc najstarsze dzieje parafii we Florynce pozostają w sferze przypuszczeń. Zakładając, że wieś od powstania do czasów relokacji w $1574 \mathrm{r}$. funkcjonowała w ramach prawa niemieckiego, fakt istnienia cerkwi a zarazem parafii prawosławnej wydaje się być wątpliwym. Prawdopodobnie więc uposażenie parafii przewidziano podczas ponownej lokacji w XVI w., jednak i z tego okresu nie zachowały się żadne przekazy źródłowe potwierdzające funkcjonowanie $\mathrm{w}$ tym czasie

\footnotetext{
Walka z kamieniem kotłowym i korozja, Katowice 1938, s. 28.

Towarzystwo Zachęty Sztuk Pięknych w Królestwie Polskim - Salon 1913, Warszawa 1913, bns. Z uwagi na fakt, iż cały niniejszy tom Rocznika Ruskiej Bursy poświęcony jest Ruskiej Republice Ludowej we Florynce, w moim artkule zagadnienie to będzie jedynie sygnalizowane.

5 Dokładny zarys monograficzny parafii prawosławnej we Florynce ujęty został w pracy: R. Dubec, $Z$ dziejów parafii prawosławnych na Łemkowszczyźnie w okresie międzywojennym, Gorlice 2011, s. 81-92.
} 
takowej - w tym miejscu warto też zaznaczyć, że pod koniec XVI w. na terenie biskupiego państwa muszyńskiego istniały tylko 4 cerkwie (Tutalak 2014, 24). Najstarsza wzmianka o parafii we Florynce pochodzi z 1623 r., kiedy to biskup krakowski Marcin Szyszkowski uposażył w niej parafię. Z uwagi na prowadzoną przez biskupów w swych dobrach akcję katolizacyjną, uposażane przez nich parafie musiały być już unickie. W tej sytuacji można przyjąć dwa warianty. Według pierwszego, parafia prawosławna istniała we Florynce już w XVI w., a po przyjęciu unii, w 1623 r., została (ponownie) uposażona. Według drugiego natomiast, bardziej prawdopodobnego, pierwsza parafia została erygowana, a zarazem uposażona, dopiero w 1623 r. Jednym $\mathrm{z}$ argumentów przechylających szalę na korzyść drugiego wariantu, jest notatka sporządzona przez Józefa Łepkowskiego, w której wspomina, iż we Florynce „mała cerkiewka drewniana stanęła nad brzegiem Białki w 1625 roku” (Dodatek tygodniowy do Gazety Lwowskiej 6.10.1855, 4). Budowa cerkwi w przeciągu dwóch lat od uposażenia parafii wydaje się jak najbardziej realna.

Pierwotna cerkiew była zlokalizowana na cyplu powyżej ujścia potoku Mostyszy do rzeki Białej. Miejsce, na którym stała, posiada walory obronne, ale przede wszystkim stanowi jeden $\mathrm{z}$ najwyższych punktów w wypłaszczonej dolinie, w której rozciągała się wieś. Prawdopodobnie właśnie kosztem nieulegającego zalewaniu miejsca, cerkiew zlokalizowana była na uboczu, oddzielona od wsi korytem Mostyszy, co w deszczowych miesiącach i tak na pewno utrudniało komunikację na liniach cerkiew-wieś, a także cerkiew-probostwo, gdyż to również znajdowało się w centrum Florynki. Obserwując relikty dawnego podziału łanowego Florynki, widocznego jeszcze na mapie katastralnej z połowy XIX w., można dostrzec pasowy łan, który należał do popostwa w jego ciągu, leżącym na prawym brzegu Mostyszy, zlokalizowana była cerkiew z cmentarzem oraz pola uprawne, natomiast na lewym brzegu, $\mathrm{z}$ kilkuset metrowym przesunięciem $\mathrm{w}$ kierunki południowym, znajdowała się druga część popostwa (rola plebańska), na skraju której zlokalizowana była plebania i folwark ${ }^{6}$.

Cerkiew pw. Michała Archanioła wzniesiona w 1625 r. była prawdopodobnie jedynym istniejącym $\mathrm{w}$ tym miejscu obiektem sakralnym w przeciągu dziejów. Zlokalizowana na wydatnym wzniesieniu, obwiedziona była kamiennym ogrodzeniem o nieregularnym kształcie - od strony skarpy, pod którą pod koniec XIX w. wybudowano drogę Florynka-Izby (z mostem), ogrodzenie

Archiwum Narodowe w Krakowie (ANK), Kataster galicyjski zesp. 280, sygn. 2263, s. IV, k. 7. 
poprowadzono niemal prosto, wzdłuż krawędzi skarpy, natomiast w pozostałej części jego biegu uformowane jest na planie wielokąta. Pierwotnie cmentarz parafialny był zlokalizowany w granicach ogrodzenia okalającego cerkiew. Pod koniec XVIII w. obszar grzebalny rozszerzono w kierunku południowym, formując nowy cmentarz na planie zbliżonym do kwadratu, którego jeden, północno-wschodni narożnik zachodził na cmentarz cerkiewny ${ }^{7}$. Obok cmentarza znajdowała się niewielka drewniana kostnica i budynek dla grabarza. Cmentarz użytkowany był do 1935 r., kiedy wytyczono nowy w północnej części wsi, który pełni funkcję cmentarza parafialnego do dzisiaj (Zwoliński, Merena 1999, 63).

Cerkiew we Florynce była obiektem drewnianym, założonym na planie podłużnym, orientowanym. Sanktuarium i nawa nakryte były dachami namiotowymi, nad prytworem znajdowała się dzwonnica. Cerkiew nie posiadała zakrystii ${ }^{8}$. Była to niewielka świątynia, dlatego też wraz z rozwojem parafii, w 1870 r. postanowiono rozpocząć budowę nowej cerkwi. Wybrano też nową, dogodniejszą, lokalizację - obok zespołu plebańskiego. Wytyczony plac cerkiewny w części wschodniej znajdował się w ogrodach plebańskich. Pozostałe działki parafia musiała już pozyskać. Budowę nowej murowanej cerkwi ukończono w 1875 r. Wyposażenie świątyni (m.in. ikonostas i ołtarze) zakupiono ok. 1880 r. W tym czasie wykonano również dekorację malarską obiektu, programowo nawiązującą do Chrztu Rusi.

Około 1860 r. wzniesiono budynek nowej plebani oraz nowe budynki folwarczne.

W 1910 r. rozpoczęto starania o gruntowny remont cerkwi i budynków plebańskich. Przy cerkwi zakres prac obejmować miał: montaż 4 stalowych okien w wieży (760 kr.), wykonanie nowych tynków na zewnętrznych ścianach budowli (170 kr.), naprawę połaci dachowych poprzez uzupełnienie i przytwierdzenie dachówek (202 kr. 80 hal.) oraz zakup 10 sztuk szklanych dachówek i ich montaż w połaciach dachowych (30 kr.), przemurowanie korony ściany cerkwi od strony północnej (170 kr.), konserwację stolarki okiennej (104kr.), okucie blachą parapetów podokiennych (12 kr.), wybudowanie muru ogrodzeniowego okalającego cmentarz cerkiewny i zwieńczenie go betonowym daszkiem (600 kr.), wykonanie systemu odwodnieniowego odprowadzającego wodę opadową z rynien (180 kr.), wybudowanie słupów i zakup metalowych

Ibidem.

Historia i architektura cerkwi we Florynce opracowane zostaną w osobnym artykule.

ANK, Kataster galicyjski zesp. 280, sygn. 2263, s. IV, k. 7. 
wrót do bramy głównej prowadzącej na teren cmentarza cerkiewnego (85 kr.) oraz wykonanie jednoskrzydłowej, metalowej furtki od strony plebanii (70 kr.), ułożenie nowej podłogi w nawie cerkwi w miejscach odsłoniętych po przesunięciu ław (120 kr.) oraz wymianę drewnianej podłogi w izbicy dzwonnicy (30 kr.). W budynku plebanii natomiast planowano wykonać: konserwację stolarki okiennej (144 kr.) i drzwiowej z wymianą elementów ślusarskich (224 kr.), nowe drzwi prowadzące do werand od strony frontowej i tylnej (100 kr.), nowe podłogi w kuchni i pokojach (1097 kr.) oraz betonową posadzkę w sieni (67 kr.), wymianę podbitek i otynkowanie sufitów w kuchni oraz w jednym z pokoi (74,75 kr.), nową kuchnię kaflową z piecem piekarskim oraz zakupić armaturę kuchenną (345 kr.), restaurację 6 pieców kaflowych w pokojach (990 kr.), nowy, murowany, dwudziałowy wychodek z drewnianą ścianką działową, pokrycie go dachem blaszanym (120 kr.) oraz doprowadzenie do niego od plebanii betonowego chodnika ( $80 \mathrm{kr}$.), konserwację i uzupełnienie gzymsów podokiennych, wzmocnienie cokołu budynku oraz pobielenie wszystkich ścian zewnętrznych (140 kr.), mocowanie (172 kr.) oraz wymianę uszkodzonych dachówek ${ }^{10}$.

W czasie I wojny światowej wojsko austriackie zarekwirowało dwa z trzech dzwonów z cerkiewnej dzwonnicy. Według lokalnych przekazów największego dzwonu wojskowym nie udało się zdjąć, co uchroniło go przed zniszczeniem. W latach 20. XX w. prof. Julian Jaworski odnalazł we Florynce 4 rękopiśmienne śpiewniki pochodzące z XVIII w. Przekazano je do Muzeum Narodowego w Pradze (Horbal 2012, 35).

Pierwszym odnotowanym w źródłach duchownym pełniącym posługę we Florynce był urodzony w 1717 r. ks. Andrzej Doliński, który zastąpił nieznanego z imienia i nazwiska poprzedniego proboszcza, zmarłego przed $1760 \mathrm{r}^{11}$ Ks. Doliński jako proboszcz po raz pierwszy odnotowywany jest w $1761 \mathrm{r}^{12}$ Jego żoną była Rozalia Szczawińska (w innym źródle podawana jest Tekla z Choroszczaków) a córką Marianna, urodzona w 1760 r., która 19 listopada 1787 r. wyszła za mąż za Tomasza Krynickiego, syna proboszcza w Słotwinach. Krynicki po przyjęciu chirotonii, w lutym 1788 r. przejął od teścia, będącego już w podeszłym wieku zarząd nad parafią; ks. Doliński zmarł na plebanii we Florynce 5 czerwca 1791 r. $^{13}$ Kolejną placówką duszpasterską ks. Krynickiego

10 ANK, Starostwo Powiatowe w Grybowie, sygn. 37, Referat Gminny - Sprawy samorządowe, bnk.

11 Archiwum Państwowe w Przemyślu (APP), Archiwum Biskupstwa Greckokatolickiego (ABGK), sygn. 58, Wizytacja dekanalna dekanatu muszyńskiego 1761, k. 41-42.

12 Ibidem.

13 APP, ABGK, sygn. 6966, Kopie ksiąg metrykalnych parafii Florynka, k. 31-32; ibidem, k. 64. 
była pobliska Binczarowa, w której jako proboszcz pracował przez rok, po czym w 1801 r. wrócił do Florynki ${ }^{14}$. Od 1815 r. do końca życia pełnił funkcję administratora kapelanii w Kamiannej, gdzie zmarł w 1834 r. (Blazejowskyj 1995, 722) ${ }^{15}$. Jego następcą we Florynce został ks. Grzegorz Czyrniański ${ }^{16}$. Urodził się w 1775 r., wyświęcony został w 1801 r. Przed święceniami ożenił się Krystyną, córką wyższego duchownego greckokatolickiej kapituły lwowskiej Michała Kaniuka (Dobrowolski 1989, 18). Jego pierwszą parafią była Binczarowa, w której pełnił posługę w latach 1801-181517. We wrześniu $1815 \mathrm{r}$. otrzymał prezentę na probostwo we Florynce. 20 stycznia 1824 r. we Florynce urodził się jego syn Emilian, późniejszy profesor chemii, rektor Uniwersytetu Jagiellońskiego, współzałożyciel Polskiej Akademii Umiejętności (Zięba 1997, 16) - jego chrzest odbył się następnego dnia. Ceremonii przewodził proboszcz z pobliskich Brunar Wyżnych, ks. Jozafat Kopystiański, a chrzestnymi byli: ks. Wasyl Krynicki proboszcz z Łabowej, ks. Józef Sawkiewicz proboszcz z Nowej Wsi i Maria Hojnacka - żona ks. Jana Hojnackiego proboszcza w Czyrnej ${ }^{18}$. Ks. Czyrniański miał też kilka córek - jedna z nich 1 lutego 1848 r., poślubiła pochodzącego z Turki, z szlacheckiej rodziny Ihnasiewiczów-Jaworskich herbu Sas alumna seminarium Jana Jaworskiego (ur. 1822 r.) ${ }^{19}$. Po święceniach (1848 r.) ks. Jaworski przez dwa lata praktykował jako wikary we Florynce. W tym czasie, 20 marca 1849 r. urodził się Walery Jaworski, późniejszy lekarz, jeden z pionierów polskiej gastrologii (Zięba 2016, 99) ${ }^{20}$. Ks. Jaworski następnie przez rok był wikarym w Krynicy, po czym przeniósł się w okolice Sanoka, gdzie piastował funkcję proboszcza w parafiach: Tokarnia (1852-1856), Górzanka (1856-1875) i Stróże Wielkie koło Sanoka (1875-1895) (Blazejowskyj 1995, 682). Prawdopodobnie w Górzance, w 1856 r. urodziła się ich córka Helena, która w roku akademickim 1897/1898 studiowała jako hospitantka na Wydziale Filozoficznym Uniwersytetu Jagiellońskiego (Zięba 2016, 98). Ks. Grzegorz Czyrniański pełnił szereg funkcji w strukturach cerkiewnych: co najmniej od 1824 r. był wicedziekanem, a od 1827 r. do śmierci - dziekanem dekanatu muszyńskiego a także inspektorem szkolnym okręgu muszyńskiego

14 APP, ABGK, sygn. 6952, Kopie ksiąg metrykalnych parafii Binczarowa, k. 76-81.

15 APP, ABGK, sygn. 6966, k. 3; APP, Administracja Apostolska Łemkowszczyzny (AAŁ), sygn. 69. Wykaz duchownych poszczególnych parafii od 1601 do 1942, k. 86.

APP, ABGK, sygn. 6966, k. 152-153.

APP, ABGK, sygn. 6952, k. 81-129.

APP, ABGK, sygn. 6966, k. 209.

APP, ABGK, sygn. 6967, k. 196.

Ibidem, k. 202. 
oraz tytularnym radcą konsystorza przemyskiego do spraw szkolnych (Zięba 1997, 16). W 1831 r. mianowany został honorowym kanonikiem przy katedrze greckokatolickiej w Przemyślu (Gazeta Lwowska 12.08.1931, 1). Zmarł we Florynce 20 listopada 1852 r., pogrzeb odbył się 5 dni później ${ }^{21}$. Po jego śmierci do końca roku posługę we Florynce jak administrator dojazdowy pełnił ks. Jan Krynicki administrator kapelanii z Binczarowej ${ }^{22}$. W pierwszym kwartale 1853 r. na tym stanowisku zastąpił go administrator kapelanii w Kamiannej, ks. Lew Miejski ${ }^{23}$. W maju 1853 r. stanowisko administratora we Florynce objął Wasyl Durkot ${ }^{24}$. Urodził się 1827 r., był żonaty. Wyświęcony został w Przemyślu w 1852 r., a po trzech latach został przeniesiony do Bednarki w dekanacie bieckim, gdzie do 1870 r. pełnił funkcję administratora kapelanii. Następnie objął probostwo w pobliskiej Woli Cieklińskiej. Zmarł 14 maja $1873 \mathrm{r}^{25}$

W maju 1855 r. administrację parafii we Florynce objął ks. Sylwester Wisłocki ${ }^{26}$. Urodził się w 1784 r. Przed przyjęciem święceń w 1808 r. poślubił Antonię ze Stuków. Uprzednio pełnił funkcję proboszcza w Bednarce (do 1830 r.) i w Męcinie Wielkiej (w latach 1830-1855). W Męcinie jego córka Anna 13 września 1830 r. wyszła za mąż za Antoniego, syna ks. Teodozego Sembratowicza - proboszcza w Krynicy, alumna wiedeńskiego „Barbareum”, który po święceniach w tym samym roku objął parafię w Nowej Wsi (1830-1832) a następnie w Banicy (1832-1833) ${ }^{27}$. W 1833 r. otrzymał prezentę na zamożne probostwo w Desznicy w dekanacie dukielskim. Tam, 9 września 1836 r., urodził się jego syn Sylwester, który otrzymał imię po dziadku, ks. Sylwestrze Wisłockim ${ }^{28}$. Droga kariery kardynała Sylwestra Sembratowicza, jako duchownego i polityka jest powszechnie znana, dlatego ograniczę się tylko do jednej wzmianki - po święceniach kapłańskich i uzyskaniu tytułu doktora teologii, w 1861 r. wrócił z Rzymu do Galicji i przez rok pracował w parafii dziadka we Florynce jako prywatny wikariusz (Kuryer Poznański 8.03.1885, 1).

\footnotetext{
21 APP, ABGK, sygn. 6967, Kopie ksiag metrykalnych parafii Florynka, k. 291.

22 Ibidem, k. 292.

23 Ibidem, k. 294.

24 Ibidem.

25 Archiwum Państwowe w Rzeszowie Oddział w Sanoku, Akta stanu cywilnego Parafii Greckokatolickiej w Woli Cieklińskiej sygn. 1146, Libro Metrices Mortuorum pro parochia Wola Cieklińska pro Anno Domini 1873, bnk.

26 APP, ABGK, sygn. 6967, k. 299.

27 APP, ABGK, sygn. 6924, Kopie ksiąg metrykalnych parafii Męcina Wielka z filiami Pstrążne, Rozdziele, Wapienne, k. 230.

28 APP, ABGK, sygn. 6818, Kopie ksiąg metrykalnych parafii Desznica z filią Brzozawa, k. 116.
} 
W marcu 1862 r. przeniósł się do Tylicza, skąd po kilku miesiącach oddelegowany został do diecezji lwowskiej (Gazeta Narodowa 26.02.1885, 2; Kurjer Lwowski 5.08.1898, 5). Ks. Sylwester Wisłocki zmarł we Florynce w 1863 r. (Blazejowskyj 1995, 882) ${ }^{29}$. Po nim parafię jako administrator przejął dwudziestotrzyletni ks. Konstanty Chylak ${ }^{30}$. Była to jego pierwsza parafia. Po roku został przeniesiony jako kapelan do Wojkowej. W 1864 r. ks. Chylak otrzymał probostwo w Radocynie, a następnie w Mochnaczce Niżnej (1880-1894). Ostatnim jego probostwem była Litynia w dekanacie drohobyckim, gdzie zmarł w 28 marca 1898 r. (Blazejowskyj 1995, 889). Jego następcą we Florynce mianowano ks. Atanazego Czyrniańskiego, urodzonego w 1806 r., wyświęconego w 1842 r., uprzednio pełniącego funkcję administratora w Wojkowej (1842-1864). Czyrniański zmarł na cholerę w czasie epidemii 25 sierpnia 1873 r. Pochowany został następnego dnia na cmentarzu epidemicznym we Florynce (Gazeta Lwowska 21.11.1873, 4) ${ }^{31}$. Przez rok zastępował go administrator parafii w Binczarowej ks. Justyn Konstantynowicz ${ }^{32}$. W 1874 r. prezentę na wakatujące probostwo florynieckie otrzymał ks. Michał Rydzaj ${ }^{33}$. Urodził się w 1822 r., święcenia przyjął w 1852 r. Jego pierwszą parafią, którą administrował było Łosie w dekanacie bieckim (1852-1855), w 1855 r. przeniesiony został do Leszczyn, w których funkcję proboszcza sprawował do $1873 \mathrm{r}$. Dzięki jego staraniom wzniesiono i wyposażono nową cerkiew we Florynce. Zmarł 2 lipca 1888 r. i pochowany został jako pierwszy i ostatni duchowny na cmentarzu przycerkiewnym obok nowej cerkwi we Florynce ${ }^{34}$. Po jego śmierci przez rok probostwo pozostawało nieobsadzone, a posługę pełnił proboszcz Binczarowej, ks. Teofil Kaczmarczyk ${ }^{35}$. W tym miejscu warto podkreślić, że w późniejszych dziejach Florynki niezmiernie ważną rolę odegrał jego syn, Jarosław Kaczmarczyk - doktor praw, polityk, działacz społeczny i publicysta, przewodniczący Komitetu Wykonawczego Ruskiej Republiki Ludowej we Florynce (Zięba 2016, 100). Przez dwa miesiące - od 3 marca do 1 czerwca 1889 r. parafią administrował ks. Wasyl Stefan Kuryłło, którego biogram przedstawiony zostanie w dalszej części tekstu (Пpax 2015, 407). W 1889 r. probostwo we Florynce otrzymał ks. Jan Przysłopski. Urodził się on 20 października $1831 \mathrm{r}$.

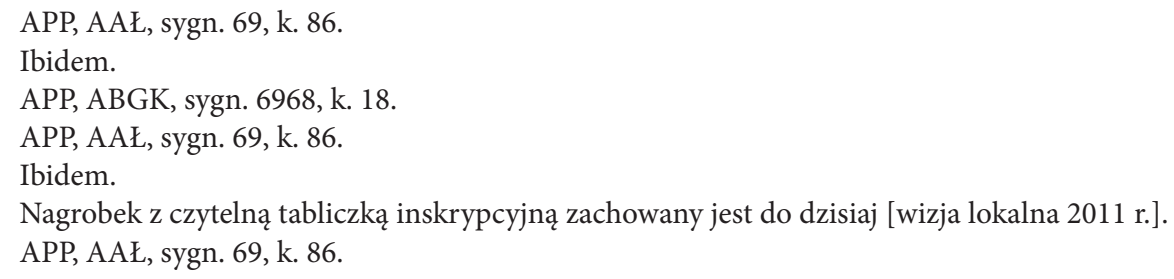


w Kamiannej w rodzinie chłopskiej ${ }^{36}$. Przed święceniami, 31 sierpnia 1858 r. poślubił Annę, córkę ks. Michała Przysłopskiego, proboszcza w Regietowie Wyżnym, i Pelagii z Małogłowskich (córki proboszcza w Hołosku Wielkim ob. dzielnica Lwowa) $)^{37}$. Pierwszą jego parafią była Wysowa, gdzie w latach 1858-1860 pracował jako wikary. W 1860 r. objął funkcję administratora parafii $^{38} .22$ sierpnia 1860 r. w Wysowej urodził się jego syn, Nestor Przysłopski, późniejszy doktor praw, adwokat m.in. we Lwowie, w Żabiem i w Gorlicach (Wiener Zeitung 2.06.1910, 4; Horbal 2013, 153) ${ }^{39}$. Następnie ks. Jan Przysłopski był proboszczem w Binczarowej (1861-1871), Żegiestowie (1871-1879) i Brunarach Wyżnych (1879-1889) (Blazejowskyj 1995, 815). Ks. Przysłopski był autorem obszernego szkicu „Ruś Sandecka” opublikowanego pod pseudonimem Ioan Petrowycz we lwowskim „Haliczaninie” w 1898 r., a następnie przedrukowanym w „Łemku” w 1911 r. (Гринченко 1901, 219). Zmarł we Florynce 5 marca 1909 r., pochowany został na cmentarzu parafialnym (nagrobek nie zachował się) $)^{40}$.

Kolejnym duchownym administrującym parafią we Florynce mianowany został ks. Stefan Wolański. Urodził się 10 stycznia 1880 r. w Czerteżu koło Sanoka. Przed święceniami w 1906 r. ożenił się z Marią, córką ks. Jana Rusyniaka (długoletniego proboszcza w Królowej Ruskiej) i Wiktorii z Czyrniańskich. Początkowo pracował jako wikary w Zyndranowej (od 4 października 1906 r. do 31 grudnia 1907 r.). W 1908 r. skierowany został do Florynki jako wikary. Po śmierci ks. Przysłopskiego, 8 marca 1909 r. mianowany został administratorem parafii. Obowiązki pełnił do 15 kwietnia 1910 r., kiedy przeniesiony został jako administrator do Męciny Wielkiej. Rok później otrzymał nominację na probostwo w Smerekowcu (1 marca 1911 r.). W 1914 r. został aresztowany i internowany $\mathrm{w}$ obozie koncentracyjnym w Talerhofie. Po powrocie obowiązki proboszcza w Smerekowcu pełnił do 1920 r., skąd przeniesiony został na probostwo w Kalnikowie, którym kierował do końca wojny. W 1945 r. wraz ze wsią został wysiedlony do ZSRR i przebywał w Mościskach. Prawdopodobnie pełnił tam posługe już jako duchowny prawosławny (po

36 APP, ABGK, sygn. 6973, Kopie ksiąg metrykalnych parafii Kamianna, k. 221.

37 APP, ABGK, sygn. 6932, Kopie ksiąg metrykalnych parafii Regetów Wyżny z filiami Regetów Niżny, Skwirtne, k. 148.

38 APP, ABGK, sygn. 6942, Kopie ksiąg metrykalnych parafii Wysowa z filią Blechnarka, k. 240, 259.

39 APP, ABGK, sygn. 6942, k. 259; Dziennik Urzędowy Ministerstwa Sprawiedliwości, nr 19, 01.10.1928, s. 339.

40 APP, AAŁ, sygn. 69, k. 86. 
soborze lwowskim w 1846 r.). Zmarł w Mościskach 20 września 1952 r., pochowany został na starym cmentarzu (Blazejowskyj 1995, 877; Hałagida 2008, 412; Праx 2015, 533 ${ }^{41}$.

Kolejny proboszcz Florynki - Wasyl Stefan Kuryłł, w sposób szczególny zapisał się w historii nie tylko Florynki, ale i Łemkowyny. Urodził się 11 sierpnia 1861 r. w Lipiu (pow. turczański) w rodzinie księżowskiej - jego ojcem był pochodzący z Wysowej ks. Teodor Kuryłło - w tym czasie proboszcz Lipia i dziekan dekanatu żukotyńskiego. Wasyl Kuryłło uczęszczał do gimnazjum w Przemyślu, następnie podjął studia w seminarium we Lwowie (1882-1885) i w Przemyślu (1885-1997). Przed święceniami w 1887 r. ożenił się z Marią z Konstantynowiczów. Pierwszą parafią, którą administrował była Kamianna (1887-1889). Następnie, po wspomnianym wyżej krótkim pobycie we Florynce, objął jako administrator parafię w Brunarach Wyżnych (1889-1890). W drugiej połowie 1890 r. administrował parafiami w Roztoce Wielkiej i Uściu Ruskim. 28 grudnia 1890 r. otrzymał prezentę na probostwo w Męcinie Wielkiej (Пpax 2015, 533). W czasie dekady sprawowania tam posługi przeprowadził m.in. generalny remont drewnianej cerkwi w Męcinie. Na początku kwietnia 1910 r. namiestnictwo nadało mu regiae collationis (prezentę królewską) i już 16 kwietnia objął parafię we Florynce (Kurjer Lwowski 9.04.1910, 3). Niemal od razu rozpoczął starania o remont cerkwi i budynków plebańskich. Ks. Kuryłło, będąc jeszcze proboszczem w Męcinie, angażował się w lokalną politykę, współpracował m.in ze stronnictwem ludowym. W 1914 r. w pierwszych miesiącach wojny został aresztowany i doprowadzony do Grybowa, gdzie wraz z innymi aresztantami obrzucony został kamieniami przez zebrany tłum jako „zdrajca” i „moskofil” (Chomiak 1995, 9). Następnie został uwięziony w obozie koncentracyjnym w Talerhofie, w którym przebywał przez cały okres wojenny. W tym czasie parafia we Florynce pozostawała bez duchownego. W sierpniu 1915 r. wierni z Florynki i Wawrzki zwrócili się do Konsystorza Biskupiego w Przemyślu, iż „bez nabożeństw i praktyk religijnych nie mogą się obejść, bo mogą zejść bardzo łatwo na bezdroża”, tym samym prosząc o przysłanie do parafii kapłana rodzimego obrządku (Szczupak 2015, 59). W 1918 r. ks. Kuryłło wrócił do Florynki, która w ostatnich miesiącach tegoż roku stała się centrum życia politycznego Łemkowyny. 5 grudnia 1918 r. na polach plebańskich, podczas wiecu powołano do życia Ruską Republikę Ludową (tzw. Republikę Floryncką). W następstwie tego wydarzenia

$\overline{41}$ APP, AAŁ, sygn. 69, k. 86. 
12 marca 1920 r. ukonstytuował się rząd RRL - Komitet Wykonawczy, w skład którego wszedł również ks. Kuryłł. Po likwidacji Republiki ks. Wasyl Kuryłło nadal sprawował obwiązki proboszcza we Florynce, a w latach 1919-1926 dziekana dekanatu grybowskiego. Po konwersji większości wiernych z Florynki i Wawrzki na prawosławie (ok. 200 rodzin w samej Florynce) na terenie całej parafii pozostały tylko 33 rodziny greckokatolickie. Jak przypuszczają niektórzy badacze, w obawie iż ks. Kuryłło, podobnie jak ks. Dymitr Chylak z Izb, przejdzie na prawosławie wraz ze swoimi wiernymi, władze eparchialne z Przemyśla postanowiły przenieść go do oddalonej parafii (Dubec 2011, 83), natomiast inne źródła podają, że za decyzją pozostania przy katolicyzmie stały podeszły wiek proboszcza, problemy zdrowotne oraz życiowy dorobek, którego nie chciał utracić (Winiarczyk-Kossakowska 2004, 102). Ostatecznie ks. Kuryłło przeniesiony został w 1930 r. do Podemszczyzny w dekanacie lubaczowskim, gdzie zmarł 11 marca 1940 r. Pochowany został na miejscowym cmentarzu parafialnym (nagrobek - płyta nagrobna istnieje) (Праx 2015, 407; Horbal 1997, 43-46; Blazejowskyj 1995, 728). Ks. Wasyl Kuryłło był autorem licznych artykułów, prac z zakresu prawa kościelnego, kronikarskich i wspomnieniowych, współzałożycielem i członkiem wielu organizacji m.in. Ruskiej Bursy w Gorlicach i Instytutu „Narodnyj Dom” we Lwowie ${ }^{42}$.

W 1928 r. do Florynki jako wikary został skierowany duchowny ks. Antoni Pohorecki ${ }^{43}$. Pochodził on z Rykowa pod Złoczowem (ur. 16 czerwca 1934 r.). Po przeniesieniu ks. Kuryłły, objął zarząd nad parafią, który sprawował do 1932 r., po czym objął probostwo w Brunarach Wyżnych (początkowo jako administrator) (Пpax 2015, 415). 1 września 1939 r. został aresztowany i osadzony w Berezie Kartuskiej, gdzie został dotkliwie pobity. Zmarł 3 października 1940 r. w szpitalu świętego Łazarza w Krakowie. Pochowany został 7 października na cmentarzu przycerkiewnym w Brunarach (nagrobek zachowany, nowy) (Праx 2015, 415).

W 1932 r. parafię we Florynce objął ks. Wasyl Chrobak, urodzony w Nehrybce 29 sierpnia 1904 r. Po święceniach skierowany został do Orowego koło Borysławia jako wikary, skąd przeniesiony został na administratora parafii we Florynce. 10 marca 1936 r. otrzymał probostwo w Maciejowej. Na początku

\footnotetext{
42 Memorjał członków rusko-narodowego Instytutu „Narodnyj Dom” we Lwowie do Posłów Sejmu i Senatorów w sprawie niezałatwienia rekursu adw. Kazimierza Czarnika wnisionego w lipcu 1917 roku od reskryptu Namiestnistwa we Lwowie z dnia 15 maja 1917 r. L. 5497/pr. rozwiązującego towarzystwo, Lwów 1928, passim.

43 APP, AAŁ, sygn. 69, k. 86.
} 
II wojny światowej został aresztowany i uwięziony w Berezie Kartuskiej. Po powrocie do Maciejowej, w latach 1941-1942, obsługiwał również ekspozyturę w Nowym Sączu. Na wiosnę 1945 r. został wysiedlony do ZSRR. Zmarł w sierpniu 1954 r. w niewyjaśnionych okolicznościach w więzieniu w Kałuszu, pochowany został w mogile zbiorowej (Пpax 2015, 191). Wasyl Chrobak był ostatnim księdzem wywodzącym się z duchowieństwa diecezjalnego, który pracowal we Florynce.

W 1935 r., po utworzeniu Apostolskiej Administracji Łemkowyny, jej administrator ks. Wasyl Maściuch podjął starania o organizację na obszarach, na których był najbardziej widoczny ruch konwersyjny na prawosławie, klasztorów oo. studytów. Pierwszy z planowanej sieci domów zakonnych erygował 1 marca 1936 r. ihumen Ławry uniowskiej o. Klemens Szeptycki. Powołanie domu zakonnego zbiegło się z nagłą śmiercią ks. Maściucha (11/12 marca). Prawdopodobnie to wydarzenie zadecydowało o przyspieszeniu organizacji placówki. 16 marca 1936 r. o. Szeptycki oddelegował z Uniowa do Florynki o. Hilariona Denyszczuka i kilku mnichów, którzy najpewniej również wzięli udział w uroczystościach pogrzebowych ks. Maściucha w Desznie, a następnie w Nowej Wsi (18 marca 1936 r.) (Gazeta Lwowska 18.03.1936, 2). Dom zakonny rozpoczął swą działalność 4 maja 1936 r., a jego ihumenem a zarazem administratorem parafii mianowano o. Hilariona, który we Florynce przebywał do 4 listopada $1941 \mathrm{r}^{44}$ Do wybuchu II wojny światowej oprócz ihumena w domu przebywało jeszcze 3 zakonników (Hałagida 2008, 45; Basak 2013, 229). Studyci oprócz pełnienia obowiązków związanych z posługą, prowadzili działalność oświatową i społeczną - organizowali m.in. we Florynce kursy dla diaków (Sitek 1996, 99) ${ }^{45}$. Następcą o. Hilariona został o. Gedeon Syrojid. Urodził się 1 kwietnia 1914 r. w Wołświniu na Soklaszczyźnie w rodzinie chłopskiej (imię świeckie - Grzegorz). Po ukończeniu gimnazjum w Sokalu wstąpił od uniowskiego klasztoru, skąd oddelegowany został na studia na Papieskim Uniwersytecie Gregoriańskim w Rzymie, gdzie kształcił się również w „Pontificium Collegium Russicum” - kolegium przygotowującym księży katolickich do pracy na terenie Związku Radzieckiego. Chirotonię przyjął 9 kwietnia 1939 r. w rzymskiej bazylice pw. św. Antoniego z Padwy z rąk biskupa Aleksandra Jewrieinowa. Od początku wojny o. Syrojid przebywał w ławrze uniowskiej, skąd 4 listopada 1941 r. został skierowany do Florynki. 4 września 1942 r. powrócił

44 Ibidem.

45 Seman Madzelan (ur. 1922), w: Mniejszość w warunkach zagrożenia. Pamiętniki Łemków, red. W. Sitek, Wrocław 1996, s. 99. 
do Uniowa, a od 1943 r. przez kilkanaście miesięcy przebywał w monasterze św. Eliasza w Dorze (obecnie Jaremcze). Po likwidacji ławry w Uniowie (1946 r.), w 1948 r. o. Gedeon został aresztowany i po pięciu miesiącach aresztu we lwowskim więzieniu zesłano go do Komsomolska nad Amurem, skąd powrócił po dekadzie. Od 1960 r. był proboszczem w Pomorzanach koło Złoczowa, skąd w 1995 r. przeniósł się do reaktywowanej ławry w Uniowie (Дутка 2005, 3-4).

Na przełomie sierpnia i września 1942 r. do Florynki przyjechał o. Herman Budzyński. Urodził się 14 października 1905 r. w Przegnojowie w powiecie złoczowskim (imię świeckie - Grzegorz). Podobnie jak jego poprzednik, w latach 30. wstąpił do klasztoru w Uniowe, skąd odesłany został na studia do Rzymu. W 1939 r. razem z Grzegorzem Syrojidem otrzymał w Rzymie święcenia. Po powrocie przebywał w studyckich ośrodkach zakonnych na terenie Generalnego Gubernatorstwa. W 1945 r. był w składzie oficjalnej delegacji przedstawicieli Cerkwi greckokatolickiej ZSRR do Moskwy (spotkania z władzami świeckimi i władzami Rosyjskiej Cerkwi Prawosławnej), odmówił również udziału w „Grupie inicjatywnej na rzecz reunifikacji Kościoła greckokatolickiego z Cerkwią Prawosławną". Po kilku aresztowaniach w marcu 1946 r. zesłany został w okolice Workuty. Po zwolnieniu w 1959 r. wrócił na zachodnią Ukrainę, gdzie pracował w różnych parafiach oraz prowadził aktywne działania na rzecz prawa do funkcjonowania Cerkwi greckokatolickiej w granicach sowieckiej Ukrainy. Od 1990 r. przebywał w klasztorze oo. studytów we Lwowie, gdzie zmarł 3 stycznia 1995 r. W XXI w. osoba o. Hermana spotkała się $\mathrm{z}$ dużym zainteresowaniem mediów ukraińskich, rosyjskich a także polskich za sprawą jego proroctwa (z 1991 r.), w którym przewidywał wydarzenia polityczne na Ukrainie w drugiej dekadzie XXI w.

Pod koniec 1942 r. do Florynki skierowany został o. Andrzej Abrahamowicz. Urodził się 5 stycznia 1885 r. w Kończakach koło Halicza w rodzinie karaimskiej (imię świeckie - Zachariasz). Jego ojciec Mordechaj wraz z synem przyjęli chrzest w 1902 r. (ojciec przyjął imię Józef, natomiast syn - Adam). Adam Abrahamowicz w 1904 r. wstąpił do zgromadzenia oo. studytów. Śluby wieczyste złożył w 1908 r., przyjmując imię zakonne Andrzej, natomiast chirotonię otrzymał 9 maja 1909 r. z rąk metropolity Andrzeja Szeptyckiego w kaplicy przy klasztorze studytów we Lwowie. Do 1932 r. pracował w różnych parafiach na terenie lwowskiej archidiecezji. W 1932 r. mianowany został przełożonym monasteru św. Teodora w Kamenicy na terenie Jugosławii (obecna Bośnia i Hercegowina). Po powrocie, do grudnia 1942 r. ponownie pracował w parafiach na terenie archidiecezji lwowskiej. Po przyjeździe do Florynki, 
w styczniu objął administracją parafię w Królowej Ruskiej, a po opuszczeniu domu zakonnego przez o. Hermana (w połowie 1943 r.) pełnił posługę także we Florynce. W czasie przesiedleń ludności łemkowskiej do ZSRR, w 1945 r. został aresztowany. Po zwolnieniu wrócił do pracy we Florynce i Królowej Ruskiej. W czasie wysiedlenia Florynki w ramach akcji „Wisła” ukrywał się w Binczarowej, ale 6 lipca 1947 r. aresztowano go ponownie i mimo podeszłego wieku, 16 lipca 1947 r., bez wyroku sądowego osadzono w Centralnym Obozie Pracy w Jaworznie (nr obozowy 2639), skąd zwolniony został 12 grudnia 1948 r. (Hałagida 2012, 127-128). Po wyjściu na wolność leczył się w ośrodkach prowadzonych przez oo. Albertynów w Zakopanem, Bulowicach koło Andrychowa, Krakowie i Przemyślu. Zmarł 17 marca 1959 r. w Przemyślu i tam został pochowany (Hałagida 2012, 374).

Do akcji „Wisła” wraz z o. Andrzejem we Florynce przebywał o. Nikodem Stecura (Hałagida 2011, 34), urodzony w sierpniu 1895 r. Święcenia przyjął 16 lutego 1936 r. Przed wybuchem wojny był ihumenem uniowskiej ławry ${ }^{46}$. Po wysiedleniu pracował w różnych parafiach na Pomorzu oraz Warmii i Mazurach jako birytualista. W 1990 r. skierowany został do Cyganka koło Nowego Dworu Gdańskiego. Zmarł 7 lipca 1990 r., pochowano go na cmentarzu przycerkiewnym w Cyganku.

W latach 1945-1947 dom zakonny we Florynce był jedynym działającym ośrodkiem studyckim w Polsce. Po jego likwidacji studyci na nowo osiedlili się na terenie Polski dopiero w 1980 r. w Białym Borze, a w 1990 r. we wspomnianym wyżej Cyganku (Marecki 1997, 81).

Jeszcze przed akcją „Wisła” z uwagi na zaczynającą się osadzać we Florynce ludność polską, wieś znalazła się w obszarze zainteresowań Kościoła rzymskokatolickiego. W 1946 r. na teren Florynki oraz kilku okolicznych miejscowości został oddelegowany wikary z grybowskiej parafii, ks. Michał Żurek. Jego zadaniem było również przygotowanie struktur pod planowaną na Łemkowynie sieć parafii rzymskokatolickich. W 1948 r. w zabudowaniach należących do parafii prawosławnej osadzone zostały 3 zakonnice ze Zgromadzenia Sióstr Świętego Józefa z Tarnowa. 5 kwietnia 1949 r. duszpasterstwo we Florynce objęli księża Sercanie (Księża Najświętszego Serca Jezusowego). 29 grudnia 1951 r. została zniesiona parafia greckokatolicka i erygowana przez ordynariusza diecezji tarnowskiej biskupa Jana Stepę parafia rzymskokatolicka pw. Najświętszego Serca Pana Jezusa.

${ }_{46}$ Według inskrypcji na nagrobku o. N. Stecury. 
Niniejszy zarys jest jedynie skrótowym opracowaniem wybranych zagadnień z historii greckokatolickiej parafii we Florynce - jej dzieje wymagaja w przyszłości wnikliwego opracowania opartego przede wszystkim na niewykorzystywanym dotąd (w znacznej mierze) przez badaczy bogatym materiale źródłowym.

\section{Bibliografia}

Archiwalia

Archiwum Narodowe w Krakowie

Kataster galicyjski zesp. 280 sygn. 2263, Dorf Florynka in Galizien Sandecer Kreis.

Archiwum Narodowe w Krakowie Oddział w Nowym Sączu

Starostwo Powiatowe w Grybowie, zesp. 271

sygn. 37, Referat Gminny - Sprawy samorządowe.

Archiwum Państwowe w Przemyślu

Archiwum Biskupstwa Greckokatolickiego, zesp. 142

sygn. 58, Wizytacja dekanalna dekanatu muszyńskiego 1761.

sygn. 6818, Kopie ksiąg metrykalnych parafii Desznica z filią Brzozawa.

sygn. 6924, Kopie ksiąg metrykalnych parafii Męcina Wielka z filiami Pstrążne, Roz-

dziele, Wapienne.

sygn. 6932, Kopie ksiąg metrykalnych parafii Regetów Wyżny z filiami Regetów Niżny,

Skwirtne.

sygn. 6942, Kopie ksiąg metrykalnych parafii Wysowa z filią Blechnarka.

sygn. 6952, Kopie ksiąg metrykalnych parafii Binczarowa.

sygn. 6966, Kopie ksiąg metrykalnych parafii Florynka.

sygn. 6967, Kopie ksiąg metrykalnych parafii Florynka.

sygn. 6973, Kopie ksiąg metrykalnych parafii Kamianna.

Apostolska Administracja Łemkowszczyzny, zesp. 157

sygn. 69, Wykaz duchownych poszczególnych parafii od 1601 do 1942.

Archiwum Państwowe w Rzeszowie Oddział w Sanoku

Akta stanu cywilnego Parafii Greckokatolickiej w Woli Cieklińskiej, zesp. 1146

sygn. 1, Libro Metrices Mortuorum pro parochia Wola Cieklińska pro Anno Domini 1873.

\section{Prasa}

Czas, nr 132. 12.06.1890.

Czas, nr 34. 12.02.1892.

Gazeta Lwowska, nr 268. 21.11.1873.

Gazeta Lwowska, nr 64. 18.03.1936.

Gazeta Lwowska, nr 7. 10.01.1873. 
Gazeta Narodowa, nr 46. 26.02.1885.

Kurjer Lwowski, nr 162. 09.04.1910.

Kurjer Lwowski, nr 215. 05.08.1898.

Kuryer Lwowski, nr 233. 23.08.1902.

Kuryer Poznański, nr 55. 08.03.1885.

Tarnowianin. Kalendarz na rok 1895. Tarnów 1894.

Wiener Zeitung, nr 148. 02.06.1910.

\section{Opracowania}

Basak, Waldemar. 2013. „Działania komunistów wobec Kościoła rzymsko- i greckokatolickiego na terenie południowo-wschodniej rzeszowszczyzny w latach 1944-1947”. Resovia Sacra. Studia Teologiczno-Filozoficzne Diecezji Rzeszowskiej, nr 13.

Blazejowskyj, Dmytro. 1995. Historical Šematism of the Eparchy of Peremyšl Including the Apostolic Administration of Lemkivščyna (1828-1939). Lviv: Kamenyar.

Broch, Rudolf, Hauptmann, Hans. 1993. Zachodniogalicyjskie groby bohaterów z lat wojny światowej 1914-1915. Przeł. Henryk Sznytka. Tarnów: Muzeum Narodowe.

Chomiak, Roman. 1995. Nasz łemkowski los. Nowy Sącz: SOWy Sądecka Oficyna Wydawnicza Wojewódzkiego Ośrodka Kultury.

Czajkowski, Jerzy. 1999. Studia nad Łemkowszczyzna.. Sanok: Muzeum Budownictwa Ludowego.

Dobrowolski, Stanisław W. 1989. Memuary pacyfisty. Kraków: Wydawnictwo Literackie.

Dubec, Roman. 2011. Z dziejów parafii prawosławnych na Łemkowszczyźnie w okresie międzywojennym. Gorlice.

Falniowska-Gradowska, Alicja. 1982. Studia nad społeczeństwem województwa krakowskiego w XVIII wieku. Warszawa: Wydawnictwo Naukowe PWN.

Hałagida, Igor. 2008. „Szpieg Watykanu”. Kapłan greckokatolicki ks. Bazyli Hrynyk (1896-1977). Warszawa: Instytut Pamięci Narodowej.

Hałagida, Igor, opr. 2011. Odnowienie duszpasterstwa greckokatolickiego w Polsce 1956-1957 (dokumenty). Warszawa: Wydawnictwo „Bazyliada”.

Hałagida, Igor, opr. 2012. Działania komunistycznych organów bezpieczeństwa przeciwko duchowieństwu greckokatolickiemu w Polsce (1944-1956) (dokumenty). Warszawa: Wydawnictwo „Bazyliada”.

Horbal, Bogdan. 2012. „Łemkowskie utwory rękopiśmienne XVI-XVIII wieków i ich los”. Річник Руской Бурсы 2012.

Horbal, Bogdan. 2013. „Obecność Łemków w kulturze polskiej”. W: Łemkowie. Red. Beata Machul-Telus. Warszawa: Wydawnictwo Sejmowe.

Jewuła, Łukasz, Kargol, Tomasz, Ślusarek, Karol. Słownik miejscowości i elity wiejskiej zachodniej Małopolski w latach 1772-1815. Dostęp: 25.11.2018. https://www.gospodarkagalicji.pl.

Leszczyńska-Skrętowa, Zofia, wyd. 1968. Księga dochodów beneficjów diecezji krakowskiej z roku 1529 (tzw. Liber retaxationum). Wrocław: Zakład Narodowy im. Ossolińskich.

Laskowski, Andrzej. 2017. Korpus witraży z lat 1800-1945 w kościołach rzymskokatolickich metropolii krakowskiej i przemyskiej, t. 4: Diecezja tarnowska, cz. 1. Kraków: Imedius Agencja Reklamowa. 
Leszczyńska-Skrętowa, Zofia, Sikora, Franciszek, opr. 1980. Słownik historyczno-geograficzny ziem polskich w średniowieczu, cz. 1: Kraków. Wrocław: Ossolineum.

Marecki, Józef. 1997. Zakony męskie w Polsce. Instytuty życia konsekrowanego, instytuty i zgromadzenia zakonne, instytuty świeckie, wspólnoty życia apostolskiego. Kraków: Universitas.

Memorjał członków rusko-narodowego Instytutu „Narodnyj Dom” we Lwowie do Posłów Sejmu i Senatorów w sprawie niezałatwienia rekursu adw. Kazimierza Czarnika wniesionego w lipcu 1917 roku od reskryptu Namiestnictwa we Lwowie z dnia 15 maja 1917 r. L. 5497/pr. rozwiązującego towarzystwo. 1928. Lwów.

Przyboś, Kazimierz. 2007. „Ordynacja biskupia Franciszka Krasińskiego dla klucza muszyńskiego z 1575 roku”. Almanach Muszyny.

„Ruś Sandecka niegdyś Biskupszczyzna (Z notat podróży J. Łepkowskiego)”. Dodatek tygodniowy do Gazety Lwowskiej, nr 40. 06.10.1855.

Sitek, Wojciech, red. 1996. Mniejszość w warunkach zagrożenia. Pamiętniki Łemków. Wrocław: Wydawnictwo Uniwersytetu Wrocławskiego.

Szczupak, Adam. 2015. Greckokatolicka diecezja przemyska w latach I wojny światowej. Kraków: Towarzystwo Wydawnicze „Historia Iagellonica”.

Towarzystwo Zachęty Sztuk Pięknych w Królestwie Polskim - Salon 1913. 1913. Warszawa.

Tutalak, Ewa. „Katolicy i «cerkiewni» w «państwie muszyńskim» w XVII wieku”. Prace Naukowe PWSW. Nauki Humanistyczne, nr 1.

Walka z kamieniem kotłowym i korozja. 1938. Katowice.

Zięba, Andrzej A. 1997. „Profesor Emilian Czyrniański”. W: Łemkowie i łemkoznawstwo $w$ Polsce. Red. Andrzej A. Zięba. Kraków: Polska Akademia Umiejętności.

Zięba, Andrzej A. 2016. „Narodowość ruska na Uniwersytecie Jagiellońskim. Analiza prozopograficzna studentów obrządku greckokatolickiego z obszaru Rusi łemkowskiej 1851-1918”. Річник Руской Бурсы.

Zwoliński, Jarosław, Merena, Jarosław. 1999. Florynka (nasze seło). Na Łemkowszczyźnie. Koszalin: MKiSz Fundusz Promocji Twórczości.

Гринченко, Борис Д. 1901. Литература украинского фольклора 1777-1900. Чернигов: Земская Типографія.

Дутка, М. 2005. „Іеромонах з Волсвина”. Голос з-над Бугу, ч. 6.

Прах, Богдан. 2015. Духовенство Перемиської єпархії та Апостольської адміністрації Лемківщини, t. 1, Біографічні нариси (1939-1989). Львів: Видавництво УКУ. 